IRA-International Journal of Management \& Social Sciences

ISSN 2455-2267; Vol.07, Issue 02 (2017)

Pg. no. 281-285

Institute of Research Advances

http://research-advances.org/index.php/RAJMSS

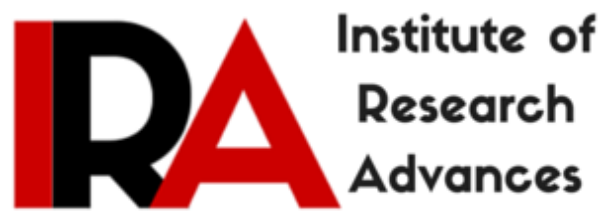

\title{
An Impact of Modi's Government on Indian Economy with Special Reference to Selected Governmental Programmes
}

\section{Dr. Prakasha N}

Assistant Professor, Department of Economics, Government First Grade College Krishnarajanagar-571602 Mysuru District, India.

Type of Review: Peer Reviewed.

DOI: http://dx.doi.org/10.21013/jmss.v7.n2.p18

\section{How to cite this paper:}

N, Prakasha (2017). An Impact of Modi's Government on Indian Economy with Special Reference to Selected Governmental Programmes. IRA-International Journal of Management \& Social Sciences (ISSN 2455-2267), 7(2), 281-285. doi:http://dx.doi.org/10.21013/jmss.v7.n2.p18

(C) Institute of Research Advances

\section{(cc) EY-NO}

This work is licensed under a Creative Commons Attribution-Non Commercial 4.0 International License subject to proper citation to the publication source of the work.

Disclaimer: The scholarly papers as reviewed and published by the Institute of Research Advances (IRA) are the views and opinions of their respective authors and are not the views or opinions of the IRA. The IRA disclaims of any harm or loss caused due to the published content to any party. 


\section{ABSTRACT}

The economy of India is the sixth largest economy in the world measured by Purchasing Power Parity (PPP). The country is classified as a newly industrialized country, one of the G-20 major economies, $a$ member of BRICS and a developing economy with an average growth rate of approximately 7 percent over the last two decades. India's economy became the world fastest growing major economy in the last quarter of 2014, surpassing the People's Republic of China. The long-term growth perspective of the Indian economy is positive due its young population, corresponding low dependency ratio, healthy saving and investment rates, and increasing integration into the global economy. This paper deals with the impact of Narendra Modi's Government on various socio economic sectors of Indian economy. This study is trying to analyse the progressively changes in various economic variables through implementing various welfare programmes in present Indian economy and after the Modi came into power.

Keywords: GDP, Government, Growth, Employment, Investment.

\section{Introduction}

Comparing India's growth vis-à-vis the slowdown in other countries, the Indian economy has been posting higher growth and has emerged as the fastest growing economy of the world. The performance of Modi government, the resolution said India's GDP had grown 7.2 percent in 2014-15 and 7.6 percent in 2015-16. It is significant to note that the last quarter witnessed GDP growth rate of 7.9 percent. Despite severe resource constraints, we could achieve fiscal deficit of 4.1 percent and 3.9 percent in the 2014-15 and 2015-16 respectively. Also better supply management and control on fiscal deficit has resulted in control of inflation.

\section{Objectives}

The study has following some objectives:

1. To know the performance of present central government programmes in general.

2. To analyse the impact of selected programmes of Modi's Government in particular.

\section{Methodology of Study}

The paper has been developed on the basis of secondary data. The data has collected through research journals, news papers, government reports and internet sources. The paper is descriptive in nature. The table is analyses through bar diagram.

\section{An Analysis of selected programmes of Modi’s Government}

The Modi's Government introduced number of welfare programmes to upliftment of vulnerable people in India. The important effective programmes are Jan Dhan Yojana for financial inclusion, Make in India for economic empowerment of nation, Swach Bharath for making good health and environment, Sukanya Samruddi Scheme (Beti Bachao, Beti Padhao) for caring for the girl child, number of labour related programmes are implemented. Among these programmes the study has taken selected few programmes discussed below.

\section{Pradhan Mantri Jan Dhan Yojana(PMJDY)}

Sixty seven years after independence, India still had a large part of the population who had no access to banking, financial services. This meant, they had neither nay avenues for savings, nor any opportunity to get institutional credit. PM Modi launched the Pradhan mantra Jan Dhan Yojana on $28^{\text {th }}$ August 2014 to address this fundamental issues. 
PMJDY is India's National Mission for financial inclusion to ensure access to financial services, namely banking savings and deposit accounts, remittance, credit, insurance, pension in any affordable manner. The scheme run by Department of Financial Services, Ministry of Finance, on the inauguration day, 1.5 crore (15 Million) bank accounts were opened under this scheme. Within a matter of months, this scheme has radically transformed lives and futures. Guinness World Records Recognizes the Achievements made under PMJDY, Guinness world Records certificates says "The most bank accounts opened in one week as a part of financial inclusion campaign is $18,096,1$ and was achieved by banks in India from 23 to 29 August 2014. By $1^{\text {st }}$ February 2017, over 27 crore(270 million) bank accounts were opened and almost 665 billion(US $\$ 10$ billion) were deposited under the scheme.

The scheme has been started with a target to provide 'Universal and clear access to banking facilities' starting with "Basic banking Accounts" with overdraft facility of Rs.5000(US\$74) after six months and RuPay Debit Card with inbuilt accident insurance cover of one lakh(US\$1500) and RuPay Kisan Card. In next phase, micro insurance and pension etc. will also be added. With the introduction of new technology introduced by National payments Corporation of India (NPCI), a person can transfer funds, check balance through a normal phone which was earlier limited only to smart phones. Mobile banking for the poor would be available through National Unified USSD Platform (NUUP) for which all banks and mobile companies have come together.

\section{Statistics of PMJDY as on $1^{\text {st }}$ March 2017 (Figures in crores)}

\begin{tabular}{|l|l|l|l|l|l|l|l|}
\hline $\begin{array}{l}\text { Sl. } \\
\text { No }\end{array}$ & \multicolumn{3}{|c|}{ Number of Accounts } & $\begin{array}{l}\text { Number of } \\
\text { RuPay Cards }\end{array}$ & $\begin{array}{l}\text { Aadhar } \\
\text { Seeded }\end{array}$ & $\begin{array}{l}\text { Balance } \\
\text { Accounts } \\
\text { in Rupees })\end{array}$ \\
\hline & & Rural & Urban & Total & & & \\
\hline 1 & $\begin{array}{l}\text { Public Sector } \\
\text { Banks }\end{array}$ & 12.21 & 10.08 & 22.30 & 17.37 & 14.25 & $50,250.28$ \\
\hline 2 & $\begin{array}{l}\text { Regional Rural } \\
\text { Banks }\end{array}$ & 4.00 & 0.64 & 4.64 & 3.45 & 2.58 & $11,810.42$ \\
\hline 3 & Private Banks & 0.54 & 0.36 & 0.90 & 0.83 & 0.40 & 2227.51 \\
\hline & \begin{tabular}{l} 
Total crore \\
\hline
\end{tabular} & 16.75 & 11.09 & 27.84 & 21.65 & 17.22 & $\begin{array}{l}64,288.21 \text { crore } \\
\text { (US } \$ 9.6 \text { billion })\end{array}$ \\
\hline
\end{tabular}

Source:PMJDY.gov.in.

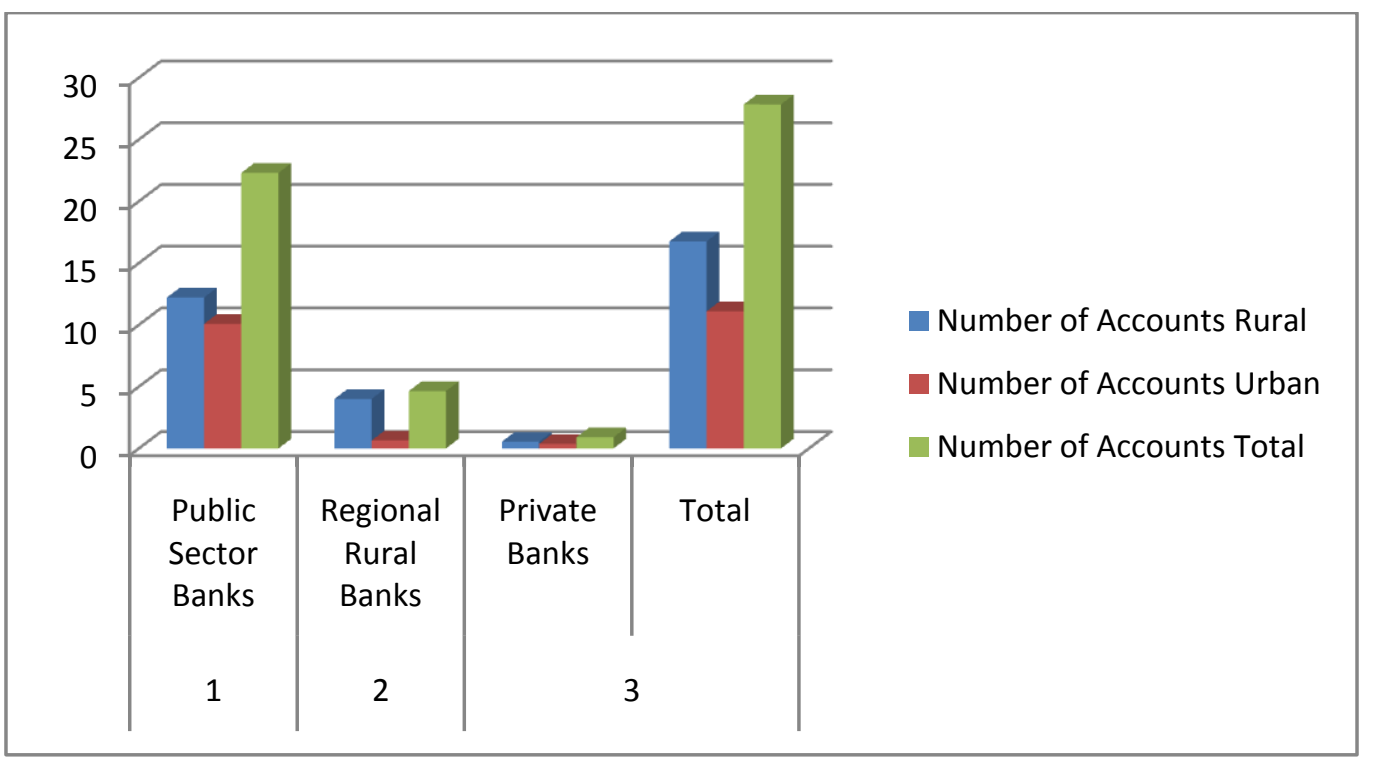


The Jan Dhan Scheme has increased to mobility of rural people towards banks and financial institutions. Life security and economic security has provided by Government to people through this programme.

\section{Make in India}

Today, India's credibility is stronger than ever. There is visible momentum, energy and optimism. Make in India is opening investment doors. Make in India initiatives was launched by Prime Minister Narenda Modi in September 2014 as part of a wider set of Nation building initiatives. Make in India is much more than an inspiring slogan. It represents a compressive and unprecedented overhaul of out-dated processes and policies. Most importantly, it represents a complete change of the Government's mindset - a shift from issuing authority to business partner, in keeping with Prime Minister's tenet of 'Minimum Government, Maximum Governance'.

Various sectors have been opened up for investments like Defence, Railways, Space, etc. also, the regulatory policies have been relaxed to facilitate investments and ease of doing business.

The major objectives behind the initiatives are to focus on job creation and skill enhancement in 25 sectors of the economy. The initiatives also aim at high quality standards and minimizing the impact on the environment. The initiatives hope to attract capital and technological investment in India. Before the initiative was launched, foreign equality caps in various sectors had been relaxed. The application for licenses was made available online and the validity of licenses was increased to three years. Various other norms and procedures were also relaxed.

One of the major plan made by Modi Government like Delhi Mumbai Industrial Corridor(DMIC) under Make in India concept. Brief discussion following below:

\section{Delhi Mumbai Industrial Corridor (DMIC)}

The DMIC is touted as the world's largest infrastructure project with a total ions estimated investment of US $\$ 100$ billion. Though its 'Make in India' campaign, the Government of India aims to invigorate the country's manufacturing sector, enhance the Country's global competitiveness, facilitate investment, foster innovation and ramp up the ease of doing business in the country. The objective of this plan is to increase the manufacturing share in the Gross Domestic Product (GDP) to 25 percent by 2025. 24 investments regions are proposed to be completed in 4 Phases with 8 under Phase -1 and a $1504 \mathrm{kms}$ long Western Dedicated Foreign Corridor is planned spanning six States making it the largest infrastructure project in the World. Upon its completion, the DMIC will create 25 million job predominantly in the manufacturing sector.

\section{DMIC expects Phase 1 to be completed by 2019. A brief description of the key projects underway is as follows:}

1. Dholera, Special Investment Region(DSIR)

2. Shendra-Bidkin Industrial Area(SBIA)

3. Integrated Industrial Township(IIT)

4. Integrated Industrial Township 'Vikram Udyogpuri' Project in Ujjain

5. Global City Project in Gurgaon

With these megaprojects at its disposal, the target is to boost employment potential two-fold multiply industrial output by three times and increase exports by four times from the region. The project is expected to fuel India's economic growth for next 20-30 years. 


\section{Conclusion}

The world' fastest growth rate for a large economy in the September 2017 quarter, yet that offered cold comfort after misery inflicted by the Governments unexpected move to remove high denomination bank notes from circulation. GDP clocked an annual 7.3 percent growth between July and September 2017, faster than 7.1 percent in the previous quarter and higher than China's 6.7 percent. The present government introduced number of welfare and employment generating programmes to increase the Indian National Income and gross employment level of India.

\section{References}

1. Chandralekha Mukerji(2016), " Two years of Narendra Modi Government: 10 Steps that transformed lives of small investors", ET Bureau, The economic Times, May 30, 2016.

2. Deepalakshmi K(2016), "Two years of Modi Government: a review", The hindu, May 25, 2016.

3. KR Gupta(2000), "Liberalisation and Globalisation of Indian Economy", Atlantic Publishers and Distributors, Vol 4, New Delhi.

4. Ruddar Datt and Sundaram(2015), “Indian Economy”, S Chand Publication, New Delhi. 